\title{
Seeing the Empire Through Lists and Charts: French Colonial Records in the Eighteenth Century
}

\author{
Marie Houllemare \\ Université de Picardie Jules Verne (Amiens) / Institut Universitaire \\ de France \\ marie.houllemare@u-picardie.fr
}

\begin{abstract}
By looking at list-making and comparative assessments of trade, this article on central administrative practices of record management aims at discussing the mobilization of archives in French colonial supervision in the eighteenth century. A Bureau des Colonies was created in the French Secretariat of the Marine in 1710: from the very outset, its main mission was to deal with the colonial records, mostly correspondence, through which the colonies were administered. Archives had been collected and classified in the Bureau des archives from 1699 onwards. But this implied an effort in the organization of papers: throughout the eighteenth century, the imperial administration created several other documentary tools that produced a simplified and ideal vision of the empire and of its place in the global order. Looking at the kinds of papers produced by the colonial administration and where these records were kept provides insight into how the central authorities understood the colonial empire. The paperwork shaped the way administrators understood empire, through operations carried out by the clerks on the records. Records were collected from all the colonies and actors, with a growing sense of being a unique agency possessing relevant records that were reduced to similar storage units by agents without field experience. In fact, archives became crucial in strengthening the empire as a political unity, under a centralized metropolitan direction, mainly after the Seven Years' War.
\end{abstract}

\section{Keywords}

archive - French colonies - eighteenth century - list-making 


\section{Introduction}

In 1789 a large document called Chart of the general trade of France with its American and African colonies from 1716 until 1786 was produced for the Secrétaire d'Etat de la Marine (French Minister of the Navy). ${ }^{1}$ Written in an elegant hand on a massive sheet of paper measuring about $75 \times 45 \mathrm{~cm}$, this graphical vision of colonial trade had been commissioned by the Secretary of State, the maréchal de Castries, who was in charge of the protection and administration of the overseas colonies. Appointed in 1780 on the recommendation of the banker and finance minister Necker, de Castries had asked his officers for an overview of the colonial trade balance. The chart was intended to be used as a tool for political decision-making, and aimed at showing the growing economic importance of overseas territories for France, as well as assessing the impact of the Exclusif mitigé (a partial opening of colonial trade) since 1767 .

It was obviously not the first time that the government wished to gather information about France's oversea dominions. Ministerial paperwork was first developed by Colbert under the reign of Louis XIV, but the Bureau des Colonies (Colonial Office), dedicated exclusively to the management of overseas territories, was not created at the Marine (Ministry of Navy) until $1710 .^{2}$ From the very outset, its main mission was to deal with the colonial records, mostly correspondence, through which the colonies were administered. ${ }^{3}$ Without even crossing the oceans, its commis (clerks) were experts in the production of colonial knowledge. ${ }^{4}$ Demonstrative of their expertise, the 1789 Chart can be considered as their masterpiece in the compilation and simplification of colonial realities. The tabular presentation of imperial figures was also a means to enhance the efficiency of this office and demonstrate its ability to collect and compare many sources of information, even if the figures the clerks came up with are now considered inaccurate by historians. ${ }^{5}$ The mere existence of this chart therefore embodies an increasingly efficient chain that linked

1 Archives Nationales d'Outre-Mer (АNOM), F2 C6, “Tableau du commerce général de la France avec ses Colonies d'Amérique \& Afrique depuis 1716 jusques à $1786 . "$

2 Jacob Soll, The Information Master: Jean-Baptiste Colbert's Secret State Intelligence System (Ann Arbor, 2009); and John C. Rule and Ben S. Trotter, A World of Paper: Louis XIV, Colbert de Torcy, and the Rise of the Information State (Montreal/Kingston, 2014).

3 Kenneth J. Banks, Chasing Empire Across the Sea: Communications and the State in the French Atlantic, 1713-1763 (Montreal/Kingston, 2002).

4 Chandra Mukerji, "Jurisdiction, Inscription, and State Formation: Administrative Modernism and Knowledge Regimes," Theory and Society 40, no. 3 (2011): 223-245.

5 See Jean Tarrade, Le commerce colonial de la France à la fin de l'Ancien Régime. Evolution du régime de l'Exclusif de 1763 à 1789 (Paris, 1972); and Loïc Charles and Guillaume Daudin, "La collecte du chiffre au XVIII ${ }^{\mathrm{e}}$ siècle: le Bureau de la balance du commerce et la production des 
information to archive, through operations of collecting, filing, summarizing, simplifying, organizing and comparing data, and finally keeping them in a permanent repository. 6

All these interlinked operations were instrumental in strengthening the authority of the Marine over colonial matters. While competing with other commercial and political institutions, the Marine became the dominant center of colonial command, especially when, in the 1770s, it took over the management of colonies previously run by trade companies, even if many official papers were still kept in private collections. From 1764 to 1789 all the colonial records of the Marine were progressively moved from Paris to Versailles, bringing them closer to the daily administration in order to further centralize the colonial government and make all the information available to the Secrétaire d'Etat de la Marine at close hand. The chart aimed at symbolizing the mastery of the Minister who acted as an imperial viceroy by managing all the colonies and was the only one able to fully grasp at a glance the meaning of a century of overseas commercial exchanges. The Marine was also becoming the source for the writing of an official colonial history in an attempt to respond to Raynal's Histoire des deux Indes which, since 1770, had been a public challenge to its authority. ${ }^{7}$

Rather than mapping all the archive containing documents coming from the colonies, this article seeks to explore this attempt at centralizing colonial authority through paperwork and archival practices. Two closely interwoven strands ran through the Marine's ambition: the aim of being an overseas communication center and that of being a major repository of official colonial memory. Unfortunately, excavating the process leading from the mere collection of colonial information to the centralized production of knowledge is complicated by the subsequent reclassifications of Marine records by nineteenth-century archivists and the dispersion of colonial papers between

données sur le commerce extérieur de la France," Revue d'histoire moderne et contemporaine 58, no. 1 (2011): 128-155.

6 Ben Kafka, "Paperwork: The State of the Discipline," Book History 12 (2009): 340-353; Staffan Müller-Wille and Isabelle Charmantier, "Lists as Research Technologies," Isis 103 (4): 743-752; and Isabelle Laboulais, "La fabrique des savoirs administratifs," in Histoire des sciences et des savoirs (gen. ed. Dominique Pestre), vol. 1: De la Renaissance aux Lumières, ed. Stéphane Van Damme (Paris, 2015), 447-463.

7 Marie Houllemare, "Les archives du secrétariat d'Etat à la Marine, âme de l'histoire de l'Amérique française au XVIII siècle?," De l'observation à l'inscription: les savoirs sur l'Amérique entre 1650 et 1790 dans les textes d'expression française, ed. Nathalie Vuillemin and Thomas Wien (Oxford, 2017), 121-130. On Raynal's relationship with the Marine, see François Moureau, "L'abbé Raynal et la fabrication d'un best-seller: de l'agent d'influence à l'apôtre," Dix-huitième siècle 43, no. 1 (2011): 550. 
various state collections in the French National Archive. ${ }^{8}$ While the general expansion of the colonial archive within the Marine is well-known, the practices and significance of archival management for empire building, such as those that had made the Chart possible, call for further study. By looking at the production of humble tools of knowledge such as lists and comparative trade estimates, this article on the central administrative practices of records management aims at discussing how records and archives contributed to the French colonial supervision and affirmation of a central authority concerned mainly with the defense of metropolitan interests.

Throughout the eighteenth century, the imperial administration created several other documentary tools that produced a simplified and ideal vision of the empire and of its place in the global order. To account for this evolution, I will first describe the collection and classification of records that led to a centralization of records in the Bureau des Colonies. Then I will look at two kinds of instruments of knowledge produced by the ministerial clerks and at how these records were used in decision-making. Lists had become part of the daily management of data on colonial civil servants by the 1750 , therefore allowing a precise estimation of the financial cost of the empire. By the 1770 s, figures and charts were used to produce new comparative colonial knowledge and establish economic estimations of the colonies. Records and archival materials were jointly mobilized together to produce knowledge, both influencing the ministerial understanding of colonies and supporting the claims of the Marine as the main colonial authority in France.

\section{Institutionalization of Colonial Papers in the Eighteenth Century}

Overseas recordkeeping became a concern when Colbert was appointed first Secretary of State for the Marine in 1669, as this "information master" was very attentive to information management and to recordkeeping. ${ }^{9}$ The institutionalization of a proper archive, however, was only undertaken in 1699, when a Bureau des archives (Archive Office) was created within the Marine. Colonial documents were initially kept among maritime papers. This office operated from Paris, whereas the rest of the Marine department was in Versailles, near

8 Etienne Taillemite, "Les archives des colonies françaises aux archives nationales," Gazette des archives (1964): 93-116; and Marie Houllemare, "La fabrique des archives coloniales et la conscience impériale (France, XVIII siècle)," Revue d'Histoire Moderne et Contemporaine 61, no. 2 (2014): 7-31.

9 Soll, Information Master; Rule and Trotter, $A$ World of Paper. 
the king. ${ }^{10}$ As head of the Bureau des archives, Nicolas Clairambault, was in charge of collecting and itemizing all useful papers that were kept either in offices or by individuals: treaties, letters, financial records, staff files, reports, maps, etc. The first type of document to be collected was titles of ownership justifying possession of overseas territories. Clairambault started by looking for master copies of French establishments in Canada, the West Indies and India that Jacques Savary, the author of a famous trade handbook, Le parfait négociant (1675), had borrowed in 1687 with the permission of the King's Council. ${ }^{11}$ Such records could only be seen by the Secretary of State, or with his written approval. They were used to support the diplomatic discourse legitimizing French conquests, for instance during negotiations with Britain about the limits of Acadia in $1711 .{ }^{12}$ This allowed the Bureau des archives to become the official memory keeper of the Marine, even if the documentation was admittedly incomplete. During the Régence (1715-1723), much more attention was paid to the registration of official correspondence and royal orders: they were considered a useful tool for an efficient government of the colonies and were more regularly filed.

Scientific knowledge was also a major concern. Since 1702, maps had been carefully kept in ninety-seven portfolios classed on storage racks, next to the papers. However, the frequent consultation of this rapidly growing collection led to the opening of a new office, the Dépôt des cartes et plans (Maps Office), in 1720. Under the supervision of the chevalier de Luynes, and later of a cartographer, Jacques-Nicolas Bellin, it became a map production workshop to which the monarchy conceded an official monopoly on nautical charts in 1773. It actually became a major center dedicated to "colonial science": for instance, it published the three volumes of the Encyclopédie méthodique about the Marine (1783-1787). It was dedicated to maritime and technical knowledge, thanks to such figures as Duhamel du Monceau, who was a scientific advisor and general inspector of the Marine from 1739 onward. Among Duhamel's many initiatives was the publication of the Description of arts and crafts $(1757-1780) .{ }^{13}$

10 Etienne Taillemite, "Les archives et les archivistes de la Marine des origines à 1870," Bibliothèque de l'Ecole des Chartes 127, no. 1 (1969): 27-86; and Les archives de la marine conservées aux archives nationales (Vincennes, 1991).

11 Archives Nationales (AN), Marine (Mar), 1 B 8 1, f. 14.

12 François Ternat, Partager le monde: rivalités impériales franco-britanniques, 1748-1765 (Paris, 2015); and Houllemare, "Archives."

13 He also opened a school for navy engineers in 1741, known at the Ecole de Paris. He gave his personal collection of ship models to the king in 1748, which formed the basis for the Marine collection (nowadays Musée national de la marine in Paris). 
It followed the vast survey of natural resources (Enquête du régent) whose results had been made public in 1716-1718. ${ }^{14}$

Both initiatives were major attempts at large scale resource inventories. The very notion of resource expanded throughout the seventeenth and eighteenth century. ${ }^{15}$ It had long been used to estimate military manpower, but considering civil officers in terms of resources is not attested in colonial papers until the mid-eighteenth century. ${ }^{16}$ From this period onwards, much attention was devoted to the personal files of military and civil servants in the central administration of the Marine as well as in the colonies. The records kept in the Bureau des archives were used for several purposes: as evidence when auditing the accounts, to develop a centralized management of colonial staff and, no less importantly, as material to write the history of the French Marine and its heroic deeds. ${ }^{17}$ Archival collections were also used to provide evidence for particular individuals in need of certificates of authenticity, titles of nobility or pensions.

Yet, the most recent colonial records still tended to remain at the Bureau des Colonies, created in $1710 .{ }^{18}$ Based in Paris, not in Versailles, this service was in charge of managing the entire overseas colonial administration. In 1757, it employed nine clerks out of ninety-one for the whole ministry, which made it the third largest service of the Marine. This second documentation center was mostly devoted to recent departmental activity. Its agents were in charge of registering incoming correspondence and of preparing ministerial reports, as well as archiving all kinds of papers coming from the colonies, such as official orders, letters, memoirs, censuses, or ordinances. They dealt with political authority and international competition.

Still, it did not collect all official colonial information and its claim to comprehensiveness was challenged by many other repositories, either private or public. First, many officials kept their own papers, considering them as private

14 Christiane Demeulenaere-Douyère, "Une tentative d'inventaire des richesses minières de la France: l'enquête du Régent, 1716-1718," Documents pour l'histoire des techniques 16 (2008), http://dht.revues.org/753 (accessed April 10, 2018).

15 Liliane Hilaire-Pérez, "Etat, sciences et entreprise dans l'Europe moderne," Histoire des sciences, 421-422.

16 See Erica Charters, "Eighteenth-Century Empires at War: Managing Knowledge in Franco-British Imperial Wars, Manpower and State Power in the Eighteenth Century: Technologies of Knowledge in Franco-British Wars," Oxford Centre for Global History Seminar, October 2016 (unpublished).

17 Houllemare, "Les archives."

18 M. Houllemare, "Le Bureau des colonies et ses commis," in La liasse et la plume, Les bureaux du secrétariat d'Etat à la Marine sous l'Ancien Régime (1669-1792), ed. Sylviane Llinares and Jörg Ulbert (Rennes, 2017), 99-109. 
property: for instance neither Maurepas' 19 nor Vaudreuil's papers were part of its collections. ${ }^{20}$ Many papers were scattered throughout the archives of the trade companies, the largest ones being the Compagnie d'Occident based in Nantes, for Louisiana (1716-1731), and the Compagnie des Indes in Lorient. The latter Company's papers were brought to Paris in 1748 and were stored in the attic of its town headquarters (hôtel particulier). It had its own archivist, Germain Dernis, who published a collection of the Company's official papers in the mid-eighteenth century, whereas ministerial collections remained secret. $^{21}$ There were also scientific collections in other institutions, such as the Académie de Médecine, which had been put in charge since 1776 of a general survey about the effects of the environment on health and epidemics: data about weather and diseases were collected from every province, including overseas colonies. ${ }^{22}$ Similarly, the correspondence of missionary orders is still scattered in many libraries and archives.

Nevertheless, a few places were identified at the time as official repositories dedicated to colonial matters: mainly the Bureau des archives de la Marine, and the Maps and Charts repository in Paris; the Colonial offices of the Marine in Versailles and Rochefort; and the East India trade company offices in Lorient and Paris. The growing centrality of Paris was part of the making of what some historians have termed "world-cities": Paris was about to become an imperial capital and a site for colonial knowledge thanks to its scientific as well as administrative institutions. ${ }^{23}$ But whereas colonial propaganda was constructed through books and academic events, imperial administrative archives were devised as a tool for ministerial use only.

19 His working and personal papers were kept in a private collection until a sale in 1962: much of his correspondence then went the French Archives Nationales. Some of his papers were bought by Cornell University Library, by the Winterthur Museum, by the University of Rochester, and by Ohio State University Library.

$20 \quad$ Huntington Library.

21 Recueil des édits et déclarations concernant les compagnies de Guinée et du Sénégal (Paris, 1754); Recueil ou collection des titres, édits, déclarations, arrêts, règlemens et autres pièces concernant la Compagnie des Indes orientales établie au mois d'août 1664, précédé d'un Avertissement historique, par le sieur Dernis (Paris, 1755-1756). Germain Dernis's publication was one of the sources used by Raynal (Moureau, "L'abbé Raynal": 550).

22 Jean Meyer, "Une enquête de l'Académie de médecine sur les épidémies (1774-1794)," Annales. Economies, Sociétés, Civilisations 21, no. 4 (1966): 729-749. Virginie Tournay, "Le concept de police médicale. D'une aspiration militante à la production d'une objectivité administrative," Politix 77, no. 1 (2007): 173-200.

23 François Regourd, "Capitale savante, capitale coloniale. Sciences et savoirs coloniaux à Paris aux XVII e et XVIII ${ }^{\mathrm{e}}$ siècles," Revue d'histoire moderne et contemporaine 55, no. 2 (2008): 121-151; and James E. McClellan III and F. Regourd, The Colonial Machine: French Science and Overseas Expansion in the Old Regime (Turnhout, 2011). 
After the Seven Years' War, the reform of colonial administration tended to broaden the scope of these ministerial repositories to encompass a growing interest in "governmentality." ${ }^{24}$ They reinforced the centrality of the Marine services in that respect. There were several reasons for the new archival policy that was implemented from 1758 onward. First, Berryer was nominated as Minister of the Marine in October 1758, only a few months after the loss of Louisbourg. Previously head of the notoriously efficient Parisian police (17471757), Berryer had expanded its surveillance missions by developing several departments such as security, publishing (Librairie) and a vice squad (Moeurs). By doing so, he had also been instrumental in developing its individual files on thieves, authors, publishers and prostitutes. ${ }^{25}$ Whereas one of his predecessors, Maurepas, the Minister for the Navy from 1723 to 1749, had kept all his working files among his private papers, it can be safely assumed that Berryer brought his interest in centralization to his new department, thereby helping to shape the scope of Marine paperwork on the police's practices.

Furthermore, with the loss of Canada and several other colonies in 1763, the Marine had to deal with documents brought back from America. From the fall of Louisbourg in July 1758 until after the Treatise of Paris in 1763 , refugees arrived with many official records. This is why the intendant of Rochefort asked for the creation of a Dépôt des papiers publics des Colonies (Office for Public Papers of the Colonies). By keeping copies of civil registers, the office could help find missing people and verify identities. At first, it was only dedicated to the former Nouvelle-France (Canada), but by 1765 its scope was enlarged to the whole empire. The administrators of all the colonies were then required to send copies of civil registers every year. Copies of notarized acts and deeds were to be sent to this new colonial repository, which enlarged the vision of the colonies while remaining quite selective. In fact, these records focused mostly on certifying legal deeds and statuses, and mostly concerned free people of European ancestry and their property. This means that few documents about slaves and free people of color were included, except when legal property was at stake, through deeds of manumission for instance. In 1771, a Bureau du contentieux des colonies (Colonial Litigation office) was also created within the Marine. Its clerks received all the individual petitions and demands, filed them, and made summary notes on which the minister's decision was written in the form of a rescript. This office received copies of colonial criminal trials. True,

\footnotetext{
24 Tarrade, Commerce colonial, 67.

25 V. Denis, "Quand la police a le goût de l'archive: réflexions sur les archives de la police de Paris au XVIII e siècle," in Pratiques d'archives, $X V^{e_{-} X I X^{e}}$ siècle, ed. Maria Pia Donato and Anne Saada (Paris, 2018, forthcoming).
} 
this judicial memory was highly selective: if only slaves were involved in the criminal case, the file was destroyed. ${ }^{26}$ Still, it gave the Marine department a deeper insight into all colonial wrongdoers. It also guaranteed the authenticity of overseas records, which was further reinforced thanks to Sartine's nomination at the Marine in 1774.

As was the case with Berryer, the fact of having an efficient former Head of the Parisian police at the Marine gave a new impetus to the management of colonial papers in 1774. Only two years after his nomination, Sartine had a new records office opened in his department, which collected papers on private individuals from all the colonies. The Dépôt des Chartes des colonies (Office for Colonial Charters), created in Versailles by 1776 , was a repository with a very broad scope both geographically and thematically, maybe even larger than the police archive in the Bastille: état-civil, legal deeds, and criminal files, proof of mobility on all kinds of individuals. What had yet to be done for mainland France was first implemented for French people overseas. Still, this very ambitious project was far from gathering all the official colonial records brought to France. For instance, the records of the lost colonies stayed in Rochefort until 1789. It was only in 1791 that official papers concerning either the colonial administration or the colonists came to be stored in a single Bureau des papiers des colonies (Colonial Papers Office), that was distinct from the Bureau des archives de la Marine. Housed in a single room in the Hôtel de la guerre in Versailles, the archives reflected the Marine's vision of the empire, with a long-standing distinction between Atlantic and Asian colonies. Patrimonial and historical papers had been classified, since 1755 , according to geographic and political categories in order to give easy access to ministerial knowledge on each overseas possession. For the first time, therefore, an imperial administrative consciousness, albeit a selective one, drove the organization of official colonial records, kept in close proximity to the Minister, in a well-organized repository. Versailles was becoming the very center of an overseas empire.

\section{Human Resources Management on Paper: Getting to Know Colonial Services}

But contrary to nineteenth century archives, these colonial papers were not mere historical patrimony. The Marine archive was first and foremost designed to ensure the political management of colonies in order to serve metropolitan interests. Embodying official insight into colonial knowledge thanks to the

26 ANOM, Col E 88, file Collinet de la Salle, 220. 
authenticity and accuracy of the records, it gave the Marine extensive authority over colonial matters.

This means that the management of records and archival practices involved not only collecting a growing number of documents but also increasing their individual informative value by creating meaningful series. The Marine clerks were in charge of filing and summarizing letters, but, as so much information came from all the colonies, they also had, especially after the Seven Years' War, to find ways to make sense of it all. Collecting diverse colonial records went hand in hand with the material and cognitive operations of classification: storing papers on shelves or in cabinets but also filing them in a way that made them easy to locate and to link up. In a context of growing available data, "quick access to knowledge becomes as important as knowledge itself."27

As the paperwork increased, the need to find adequate information also led to the creation of new kinds of documents. Through various selective and interpretative operations, data was turned into knowledge. General correspondence was usually made accessible thanks to chronological registers and was geographically stored. By the late 1740 s, as in the police's offices, the clerks devised new tools to browse through this growing amount of material easily. Summaries and excerpts had been used by scholars for a long time. But the administrative management of papers also required new tools: indexes and alphabetical lists of individuals were taken from the format of encyclopedias.

List-making was indeed a "political technology" that became crucial in the understanding of colonial realities, increasingly regarded as resources rather than spaces. ${ }^{28}$ Studies on the history of military administration have shown how imprecise estimations of the army and Navy manpower, established on monstres (reviews of troops), were as late as the $1730{ }^{29}{ }^{29}$ However, it drastically improved thanks to the work of the ministerial bureaucracy and the systematic use of records. First, Laffilard, the head of the Bureau des Archives since 1739, devoted himself to organizing archival material by "alphabets." While his alphabetical index of colonial laws is no longer considered useful by scholars, a great deal of personal information can still be gleaned from his many (about 305 registers) precise lists of officers, the most famous ones being his Alphabet of military officers and his Alphabet of civil servants. ${ }^{30}$ This large census of

\footnotetext{
27 Daniel Rosenberg, "Early Modern Information Overload," Journal of the History of Ideas 64, no. 1 (2003): 1-9 (5).

28 Staffan Müller-Wille and James Delbourgo, "Introduction to Isis Focus Section 'Listmania,", Isis 103, no. 4 (2012): 711.

29 André Corvisier, Les contrôles de troupes de l'Ancien Régime (Paris, 1968 and 1970).

30 AN, Mar, $\mathrm{C}_{1} 161$ and $\mathrm{C}_{1}$ 55. Laffilard also compiled a "Genealogic list of Navy Officers" in 1749 .
} 
overseas royal agents was obviously meant to facilitate access to personal data hidden in the huge number of papers. The plan he devised and presented to the Secretary of State in 1742 comprised chronological and alphabetical lists of all post-holders, starting with the oldest records kept at the Bureau des Archives. ${ }^{31}$ Aware that the Marine had no general picture of the royal agents in the colonies, he described his work as a basis for staff-management through factchecking: based on troop inspections (revues), and therefore accurate, his lists could be used whenever an officer asked for a promotion or a bonus, in order to verify the facts alleged in his petition. ${ }^{32}$ These lists gave a general overview of all officers, and in 1763 clerks started to keep registers that kept track of all of the Marine officers' movements; for each individual, his service status, with the names of the ships, military campaigns and grades, was recorded. In 1770 a general list of all Marine officers in active service was compiled, which allowed the central administration to have exact figures about staff management. ${ }^{33}$

A second improvement in knowledge of manpower came from the Bureau des Colonies, which filed its own working papers. These records were to a large extent concerned with the memory of service, that is the royal administration, its resources and achievements, and not with overseas spaces per se, which were considered only through the lens of agents' actions and reports. All civilian positions were allocated by the Secretary of State according to information coming from the governors' and intendants' regular reports. Their (numerous) letters were filed by colony, then chronologically, among other correspondence. ${ }^{34}$ Since each letter focused on several themes at a time, in order to make sense of this huge body of material, the clerks of the Colonial Offices had to make excerpts and summaries and fill in tables and repertories.

Data on royal agents was progressively separated from this chronological filing-system. Personal files or "dossiers" were created, all paperwork on one agent being organized chronologically, aggregating reports, summaries, comments and decisions. ${ }^{35}$ This was the case for military personnel as well as civilians,

31 AN, Mar, B 8 17, Laffilard to Maurepas, January 12, 1742, quoted in M.D. Neuville, Etat sommaire des archives de la Marine antérieures à la Révolution (Paris, 1989), 316-317.

32 October 1749, "Mémoire des observations qu'on peut faire sur la table alphabétique remise à Monseigneur, contenant les services des officiers militaires de la Marine": "Comme cette table est dressée sur les revues des ports, qui sont des pièces incontestables, Monseigneur pourra, s'il le juge à propos, lorsque les officiers luy demanderont verbalement ou par placets et lettres leurs avancemens ou autres grâces, leur demander les estats de leurs services, et si ceux qu'ils donneront ne sont pas conformes à cette table, il leur fera sur cela les observations et réponses qu'il jugera convenir" (Neuville, 367 ).

33 AN, Mar C1 165 .

34 About this correspondence, see Dubé; Wien.

35 Mukerji, "Jurisdiction, inscription." 
magistrates for instance. Contrary to France, there was no venality in colonial jurisdictions, and judges were appointed by the minister of the Marine. They were under the supervision of the governor and the intendant of each colony. At the end of the seventeenth century, the reports they sent to the minister only mentioned the names, age and quality of each magistrate in a given jurisdiction. ${ }^{36}$ They grew more precise over time, providing information about magistrates' health, fortune, efficiency and docility. ${ }^{37}$ In the 1750 , intendants sent lists of all the magistrates attending any judicial session and discussed further recruitments. ${ }^{38}$ Clearly, a general picture of colonial jurisdictions could only emerge from such a vast amount of material through simplification, and, once again, through list-making. The general identification register of magistrates, organized by colony and institution, shows that the Bureau des Colonies was cognizant of 506 men working in ten Superior councils and twenty-two first instance jurisdictions during the $1760-1780$ period. ${ }^{39}$ This unique register reduced the diversity of scattered reports to simple identical units, namely jurisdictions, which called for a simple allocation of resources.

Lists, made from colonial records sent to the Marine, were the key to overseas staff management. Studied by historians of science as "research technologies," lists are also management technologies, helping, in this case, to turn men into agents and groups of men into jurisdictions. Seen from the Bureau des Colonies, jurisdictions were subcategories of "colonies," themselves being general categories for classification rather than territorial entities. An abstract ideal, "empire" was becoming the unifying principle for the distribution of resources, either agents or finance. ${ }^{40}$ Whereas the letters received gave very detailed accounts, agents of the Bureau des Colonies were in charge of producing a systematic and simplistic vision of its overseas staff, as this was necessary to make appointments and to grant gratifications accordingly, thereby strengthening its control over them. There was no prerequisite colonial qualification to be a clerk in this office, only experience with paperwork: their expertise relied on their ability to provide the Secrétaire d'Etat with up-to-date information extracted from his collections. ${ }^{41}$

36 For example, ANOM, DPPC, G1 499, December 21, 1680, list of Martinique officers.

37 For example, ANOM, Col, C8 B3, nº 40 , January 25, 1713, Martinique, Guadeloupe and Grenade.

38 For example, ANOM, Col C14 34, f. 301, March 6, 1767.

39 ANOM, $\mathrm{Col} \mathrm{D}_{2} \mathrm{C} 231$.

40 J. Andrew Mendelsohn, "The World on a Page: Making a General Observation in the Eighteenth Century," in Histories of Scientific Observation, ed. Lorraine Daston and Elizabeth Lunbeck (Chicago, 2015), 396-425.

41 Houllemare, "Bureau des colonies." 
The development of lists-compiling went with a new ability to estimate the expected costs of colonial administrative staff and therefore to define financial priorities when information on individual wages was compiled to get the general expenditure for each colony. Lists of figures were a third kind of records, also produced by the Bureau des Colonies. In 1765-1769, 1777 and 1780-1781, annual estimates of colonial spending were produced that included all wages. ${ }^{42}$ In times of colonial reform, they provided the central administration with a precise view of all the agents employed in the colonies. Data came from the colonial agents themselves, through the governor and intendants of each colony. They provided the Marine with a general overview of every colonial administration, through collections of figures, even if they were not very accurate. The estimates included both civil and military spending (of the navy and the army), without any reference to the distinction between ordinary/ extraordinary finance, and classified the royal agents according to their function. But whereas the estimation of wages, which amounted to half the total expenditure, was very precise, these documents gave only vague figures about supplies: while wages were fixed, with occasional gratifications and increases, and were calculated by simply adding up the individual salaries, figures for supplies could be easily manipulated.

Clearly, this collection of documents was meant to help make financial and political decisions on an annual basis. However, although these lists enabled comparisons between periods of time and between places, they did not come with general tables. So it was necessary to work through the various booklets to realize that, for instance, the expected cost of governing Saint-Domingue was more than four times higher in 1780 than in 1766 . When the 1781 provisional estimate was submitted to the head of the Bureau des colonies, it was still growing with an expected total of 8,440,713 livres. The choices made to reduce the deficit are indicated in the margin of the 1781 account, with a note from the Secretary of State or the head of the colonial service, which confirmed that a financial policy was implemented in response to these figures. The 1,312,946 livres deficit was only partly covered through local taxation on working slaves. So five million livres were to be sent to Saint-Domingue and expenses were to be cut, for instance by interrupting fortification work, in order to reduce spending by 500,900 livres. ${ }^{43}$

42 ANOM, F2, C8: Louisiane (1714); Saint-Domingue (1765, 1769, 1780-81); Guadeloupe (176669, 1780-81, 1788-9o); Martinique (1766-7, 1679, 1777, 1780-81, 1788-9o); Cayenne, (1766, 1767, 1769, 1780-81); Islands of France and Bourbon (1766); and Indian Ocean colonies (1781). ANOM, F2, C8, 1781, Saint-Domingue. 
Aside from chronological comparisons of one colony's accounts, comparison could also be geographical. These provisional lists of spending were indeed designed for comparisons among colonies by listing identical items that had to appear in more or less the same order for all colonies. This helped to make general differences apparent, for instance by showing the overall importance of the army in Martinique: there, its cost amounted to one third of general expenditure (compared to one fourth for Guadeloupe and for Saint-Domingue). ${ }^{44}$

But to decide on a more precise allocation of money required presenting more explicit comparative data. For instance, a comparative chart was designed in 1783 with a systematic comparison of all expenditure for Martinique and Guadeloupe for the year 1784, giving the amount and difference for each item: in total, Martinique was a third more expensive than Guadeloupe with a total difference of 148,626 pounds. ${ }^{45}$ Such a document implicitly demanded an explanation for Martinique's higher cost: were the higher expenses justified or were they a sign of bad management and corruption? In the process of translating data into figures and tables, the two islands had become abstract categories that were assumed to be similar in size. The table came with marginal notes justifying every single result, as an answer to the minister's questions. For example, missionaries' wages were estimated at 25,630 livres for Martinique and 11,576 in Guadeloupe. The difference of 14,054 livres had to be justified, and this was done by explaining that "these establishments are permanent. There are more parishes in Martinique and more Capuchins without an establishment." The difference was explained as being proportional to the size of "the service," that is of the royal administration, and not to the actual surface of each island. ${ }^{46}$ It is quite notable that the Bureau logic was functional and not geographical, reflecting royal agents' rather than colonists' interests. In fact, only two heads of the Bureau des Colonies had colonial experience: the premier commis Jean Dubuc (1764-1770), coming from Martinique, and the intendant general des colonies Guillemain de Vaivre (1783-1790), who had previously been the intendant of Saint-Domingue (1773-1780). On the contrary, the clerks involved in the presentation of data had only written sources of information and very rarely personal colonial connections. ${ }^{47}$ As a result, the production of these charts put more pressure on the accountability of local expenditure

\footnotetext{
44 ANOM, F2, C8, 1781.

45 ANOM, F 2 C 6, 204.

46 In fact, the surface area of Guadeloupe is $1,628 \mathrm{~km}^{2}$ whereas that of Martinique is $1,128 \mathrm{~km}^{2}$.

47 Houllemare, "Bureau des colonies."
} 
throughout the empire, reflecting a metropolitan and ministerial need for cutting out expenditures, rather than answering colonial demands.

Finally, it was only in the 178 os that truly comparative estimates were attempted. The Marine clerks were asked to look into their past documentation to prepare the spending estimate for 1784 . They provided the Secretary of State with a summary table of all the expenditure for the years 1773, 1774, 1776, 1777 and 1784 for the Atlantic colonies. ${ }^{48}$ For each colony and each year, the table gave the total expenditure, the taxes collected and the sum that remained to be met by the Minister. This was perhaps the first time that financial data about Saint-Domingue, Martinique, Sainte-Lucie, Guadeloupe, Tabago, Cayenne, Sénégal (Gorée, Juda), Saint-Pierre and Miquelon ever appeared on a single page. A general vision of the empire through approximate figures had finally been made available, thanks to the work done in Versailles on colonial records. It responded to the financial difficulties of the monarchy, not the colonies' interests.

\section{Economic Estimation of the Colonies}

These case studies of lists compiled in the Bureau des Colonies show that by the 1770 lists of figures and rates had become part of the administrative decisionmaking process. Record-keeping in the Marine service thus required not only filing but also carrying out new operations on documents. Clerks had to be capable of abstraction and categorization. In fine, this simplification generated new political expectations and answered metropolitan needs. Through the categories that these records produced, comparative assessments, accountability of funds and allocation of resources in the colonies emerged. Likewise, discussion of the income from colonial trade was based on archival material brought to the central colonial administration.

It was in this context of reform and enhanced paperwork that the Chart of the general trade of France with its American and African colonies from 1716 until 1786 mentioned at the beginning of this article was produced, building upon several decades of colonial records. Many numerical estimates were produced to assess the share represented by colonial trade in the national economy, even earlier than colonial administration costs at large. From these documents,

48 ANOM, F 2 C 12, Résumé des dépenses projetées pour les colonies de l'Amérique pour les années 1773, 1774, 1776, 1777 and 1784 . 
eventually epitomized in the 1789 synthesis, a growing sense of imperial unity emerged. ${ }^{49}$

The handling of commercial data received by the Marine followed the principle of double-entry bookkeeping. Louis XIV had been the first French king to learn accountancy thanks to Colbert. Regular reports on state revenues and expenses, as well as the annual account summaries on the "golden notebooks," gave him a financial expertise that could be used to run the state effectively. ${ }^{50}$ But commercial estimates coming from the colonies had been collected only since the early eighteenth century. In 1713 a statistics office was created that was in charge of delivering accounts of all international French trade to the finance minister (contrôleur général des finances). However, accounts drew on figures provided by the tax administration ( ferme générale), chambers of commerce or ports intendants and did not take colonial trade into account. ${ }^{51}$ It was only in the 1730 s that annual trade estimates were sent by civil servants in the colonies to the Marine department in France. ${ }^{52}$ By itemizing things through identical categories (quantity and value of goods, ship movements), these estimates were designed to be comparable, in order to get a clear understanding of the impact of state monopoly on trade. In other words, figures gathered from colonial port officers were a means of assessing a political project, rather than a purely economic assessment. The first known record of this kind is a 1732 estimate of goods shipped to/from the French Caribbean from/to France, Canada and the Spanish American colonies. ${ }^{53}$

The production of comparative figures is evidence of a general interest in quantification and statistics in the late eighteenth century, based on the assumption that wealth could be fully apprehended through figures and tables. ${ }^{54}$

49 The title of the document indicates that the project was started in 1787 , but the actual figures also take into account 1788 .

50 Soll, Information Master, 50-66.

$51 \quad$ Charles and Daudin, "collecte."

$5^{2}$ Moreau de Saint-Méry, t. 3, p. 312, November 20, 1731, the Secretary of State asked SaintDomingue officials for an annual estimate of trade.

53 "Comparaison du montant des marchandises apportées de France, de Canada et de la côte d'Espagne de l'Amérique aux Isles françoises du vent de l'Amérique en $173^{2}$ avec le montant de celles qui ont été aportées des mêmes pays auxdites isles en 1733 et du montant de celles qui sont sorties desdittes isles aussy pour France, pour le Canada et pour la côte d'Espagne de l'Amérique pendant chacune de ces deux années." 2 tableaux (1733), ANOM, Col C8B $17, \mathrm{n}^{\circ} 12$.

54 Karl Pearson, The History of Statistics in the 17th and 18th Centuries against the Changing Background of Intellectual, Scientific and Religious Thought (New York, 1978); Jean-Claude Perrot and Stuart J. Woolf, State and Statistics in France, 1789-1815 (London, 1984); MarieNoëlle Bourguet, Déchiffrer la France : la statistique départementale à l'époque napoléonienne (Paris, 1989); Tore Frängsmyr, J.L. Heilbron, and Robin E. Rider eds., The Quantifying 
From the 1760 , colonial finances were part of a public debate triggered by the heavy territorial and financial losses of the Seven Years' War. Public discussion then expanded to the economic interests of monopoly vs. liberalization of colonial trade. Figures had to be used to support ministerial views, as they were manipulated to support various causes. Figures were mobilized by abolitionists after 1771, when Du Pont de Nemours published his seminal Observations importantes sur l'esclavage des Nègres, a first attempt at calculating the economic interest of salaried labor versus slavery. ${ }^{55}$ However, whereas private authors could give their own approximate estimations, official figures had to be reliable and accurate.

Most of these papers were metropolis-centered (looking at trade between the homeland and the colonies) because they were supportive of the metropolitan monopolistic interests. As Ann Laura Stoler has suggested, comparison was a way to promote the interests of the imperial core. ${ }^{56}$ On the contrary, a Martinique estimate of 1777 is the oldest known attempt to promote one colony's interest within the administration by means of a tabular presentation. In this document, Botereau, a local officer in charge of collecting taxes in Martinique (directeur du domaine), carried out a comparative evaluation of active and passive trade of the colony since $1765 .{ }^{57}$ The table he came up with gave estimations of Martinique trade with France, Guinea Coast, the French, Spanish, English colonies and neutral islands. Colony-centered, it was designed to measure the effect of the opening up of colonial trade since 1765 and gave an evaluation of over a decade of commercial expansion. It used the metropolitan language of trade charts, but in order to give insight into one colony's wealth. This first case was imitated outside the colonial administration. In 1774, Abbé Raynal, in Histoire politique et philosophique ..., had merely suggested that the

Spirit in the 18th Century (Berkeley, 1990); and Eric Brian, La Mesure de l'Etat, administrateurs et géomètres au XVIII siècle (Paris, 1994).

55 Du Pont de Nemours, "Observations importantes sur l'esclavage des nègres," Ephémeride du citoyen, VI, (Paris, 1771): 224-246. See Caroline Oudin-Bastide and Philippe Steiner, Calcul et morale: coûts de l'esclavage et valeur de l'émancipation (XVIII ${ }^{e}$-XIX ${ }^{e}$ siècles) (Paris, 2015).

56 On simplification as a tool of government, see James Scott, Seeing Like a State, How Certain Schemes to Improve the Human Condition Have Failed (Yale, 1998), chapter 1; on comparison by colonial authorities, see Ann Laura Stoler, "Tense and Tender Ties: the Politics of Comparison in North American History and (Post) Colonial Studies," Journal of American History 88, no. 3 (2001): 829-865.

57 ANOM, Col C8 B 18, $\mathrm{n}^{\circ} 21$ bis, "Tableau de comparaison graduelle du commerce actif et passif de la Martinique depuis 1765 jusques et compris $1776 . "$ 
Caribbean islands were a major source of wealth for Europeans. ${ }^{58}$ But in 1785 , he published an essay based on "facts," including charts, to assess the actual affluence of colonists from Saint-Domingue with several chapters concerning the trade with the metropolis. ${ }^{59}$ It called for an official answer.

But whereas Raynal was concerned with Saint-Domingue the Chart of the general trade was a general estimate, which contrasted with the usual practices of the Marine. Contrary to French trade estimates, general estimations of colonial trade were not made regularly. Like the provisional estimates discussed above, figures were mostly requested in times of administrative reforms, i.e., in $1765,1771,1775$ and $1784-1785 \cdot{ }^{60}$ It should be added incidentally that, because the collection of data had no connection with the Finance minister, economic historians have disregarded these sources as not accurate enough and therefore useless. Jean Tarrade for instance has argued that no proper estimation can be made of Caribbean trade by using colonial administration papers. ${ }^{61}$ Still, they were important steps in the assessment of the economic importance of the colonies for France. They are also important with regard to the archival management of the colonies.

Compared to the paucity of earlier comparative attempts, and to the precise data published on Saint-Domingue, the 1789 general estimate of colonial trade is therefore a unique document. First commissioned by the maréchal de Castries (1780-1787), it was completed under La Luzerne (1787-1792). A symbolic object, signifying colonial mastery, this table was an achievement in simplification that was obtained only by a thorough search among the many records kept at the colonial services. Its very existence was a challenge to administrative knowledge of colonial resources, and at the same time it was a manifesto of the ability of the colonial administration both locally and in the Bureau des Colonies to manage their records. More broadly speaking, it also revealed the ability of the minister of the Marine to provide a full picture of colonial economic activities.

It imitated the ambition of the Tableau économique de la France by Quesnay, who had tried in 1758 to give a visual presentation of how wealth circulated in France. ${ }^{62}$ Both documents drew on the political arithmetic that had long used

58 Guillaume-Thomas Raynal, Histoire philosophique et politique des établissements, du commerce des européens dans les deux Indes 4 (1774), 198.

59 Guillaume-Thomas Raynal, Essai sur l'administration de Saint-Domingue (Paris, 1785).

6o Tarrade, Commerce Colonial, 712-717.

61 Ibid., 770-771. On the contrary, the commercial figures produced by the Statistics office gave realistic averages.

$62175^{8}$, ms. version, kept in the Mirabeau papers (AN); first impression the following year, François Quesnay, Tableau oeconomique, s. n. Versailles, 1759. 
numbers and comparisons to assess the growth of population and its political implications. Quesnay's work, trying to summarize the circulation of money in agricultural activities in order to argue for economic liberalization, was a complicated and hard to understand chart, due to its "zigzag" that connected figures from the different columns. Centered on trade rather than agriculture, the Chart of general trade was much easier to grasp, being a simple double entry table. The graphical effect sought by this synthesis in figures was a reduction of all the colonies to a single page: its visual effect can be compared to that of a general map. ${ }^{63}$ This representation of the empire on a page allowed the Marine to embrace all its Atlantic possessions at a glance. Furthermore, it reduced the diversity of incoming colonial data to a few lines that fitted on a single sheet of paper (even if a very large one). Three columns gave annual figures of imports, exports and import surpluses for 1716 and for every year from 1725 onwards, expressed in the domestic money of account, livres tournois. ${ }^{64}$ The figures it showed were in fact a matter of concern for the maréchal de Castries himself because they diverged from the estimations coming from the Statistics office. ${ }^{65}$ His clerks had to justify the differences, which were partly caused by differences in currency. Furthermore, the colonial officials were themselves very cautious about their accuracy. ${ }^{66}$ Therefore, the result highlighted the need for local officials to have a precise knowledge of trade. It was an incentive to keep more precise records, in order to fuel the ongoing public debate. ${ }^{67}$

Furthermore, the chart was chronologically divided with each era being defined by a war:

“I. Since Louis XIV's death until the downfall of the Law system

II. Continuation of Utrecht peace

III. War for the election of the Polish king Stanislas

IV. Vienna peace \& unification of Lorraine with France

V. War of Austrian Succession

VI. Aix-la-Chapelle peace

VII. Seven Years Wars in the four parts of the world

63 J Mendelsohn, "The World on a Page."

64 Livre tournois is a "money of account" that did not actually circulate but was used as a currency standard indexed to gold. One livre tournoi was worth 20 sols and 240 deniers. A colonial livre tournoi was worth one domestic livre tournoi plus 10 sols.

65 Charles and Daudin, "collecte," 148; Tarrade, Commerce Colonial, 727.

66 The intendant of Saint-Domingue, François Barbé de Marbois, sent the estimated figures but warned the minister that they were unreliable, see Tarrade, Commerce Colonial, 716, mentioning Marbois to Castries, March 24, 1787 .

67 It was most certainly communicated to other services, as the general tables of French trade for the years 1787-1789 discuss the interest of including the colonies in the balance of trade (Charles and Daudin, "Collecte," 153). 


\section{Peace of Paris}

IX. War for American liberty

X. Paris peace until the Revolution."

The chronology was driven by European wars until the mid-eighteenth century and thereafter by overseas conflicts: the "Seven Years War in the four parts of the world" (1755-1763) and the "war of the liberty of Americans" (1775-1783). Whereas since the sixteenth century geographical conceptions had reflected a global sense of unity on Earth, it was only with the Seven Years' War that overseas expansion was seen by the Bureau des Colonies as driven by worldwide conflicts and competition. ${ }^{68}$ The 1763 peace was also understood to be the tipping point of commercial take-off: in the table, the 1764 surplus appears as twelve times the 1763 surplus. It was a major landmark in arguing for the importance of colonial trade. This table was also a way to conceive of the colonial expansion over a century, therefore reshaping the colonial past through economic concerns. It allowed for a general understanding of overseas expansion.

Still, no comparison of the colonial income and administrative costs was attempted. This in itself indicates that such a table was made to support colonial expansion and trade liberalization, to argue for royal investment in colonies. By showing the ability of the Secretary of State for the Marine to sift through local data and to offer a general synthesis comparable to the documents produced by the statistics office, the chart was also a way to bolster the idea that the handling of the colonies by the secretary of state was efficient, thanks to its archive. Ultimately, in fact, its records were the only valid material through which the colonies were apprehended by the central administration: through them, colonial "operational facts" were established and used for colonial management. ${ }^{69}$

Lists were also a basis for inter-imperial comparisons, as is shown by the drafting, also in 1787, of a general estimate of Population and culture of the English and French Caribbean. ${ }^{70}$ It gave figures about white and black populations, as well as exports, resulting in the advantage of France. The French data came from the general estimates in the Bureau des Colonies, as well as from the governors and intendants of colonies. Still, contrary to the publication of the 1781 Compte-rendu au roi, all these colonial tables were kept secret and mostly used for administrative accountability and decision-making.

68 Jean-Marc Besse, "Cartographie et grandeur de la terre," in Histoire des sciences et des savoirs, 158 .

69 Scott, Seeing Like a State, 83.

70 ANOM, F 2 C6, pp. 141-145. 
Ultimately, by commissioning the General chart, the maréchal de Castries reformed data-collecting within colonies and boosted the Marine's archival and bureaucratic apparatuses. Historians have warned about the risk of using central imperial archives to write colonial history. ${ }^{71}$ Central archives are selective and give a biased vision of colonies. But the archaeology of colonial paperwork in France, especially after the Seven Years' War, shows that records and archives were crucial at the time in strengthening the Marine as the imperial core, the unique centralized metropolitan Ministry, giving the colonies a sense of unity. Collecting colonial archives was indeed an act of imperial control, but paperwork and clerks' expertise were instrumental in the Marine's overseas mastery. At first, the French colonial central archive was mostly made of correspondence. But a transformation in scope and document management by the eighteenth century led to an expansion of the type of records that caught the interest of the Secretary of State for the Marine, in particular more and more data about individuals and about trade. Not only did the clerks of the Bureau des Colonies gather material from all the overseas territories under French rule, they increasingly worked to select and reorganize data through figures and lists, thus affirming themselves as proper experts. By ample compilations, indexes and summaries in figures, new administrative tools for longdistance administration were created by paperwork on the colonial archive. One shift was the interest in a precise assessment of manpower; another was the concern about trade estimations and proof of expansion. Establishing lists and tables was a way to turn it into knowledge that would prove helpful for policy-making. In this process, colonies as spaces became rubrics and items that were to be compared. This reduction enabled the minister and the Head of the Bureau des Colonies to get a general picture of the colonies that influenced in turn the gathering of data from colonies. Through these processes of confronting, comparing, and categorizing through geographical rubrics, a sense of unity emerged after the Seven Years' War among the many detailed papers sent to the Colonial services in the Marine. In fact, it can even be argued that the very notion of empire, as a unifying principle, emerged from these cognitive operations made by the clerks on their department's archives.

71 For instance, Gregory Mann, "Locating Colonial Histories: Between France and West Africa," American Historical Review 110, no. 2 (2005): 409-434. 